\title{
Steaming Inactivates Phytophthora ramorum, Causal Agent of Sudden Oak Death and Ramorum Blight, from Infested Nursery Soils in California
}

\begin{abstract}
Wolfgang Schweigkofler, Department of Natural Sciences and Mathematics, Dominican University of California, 50 Acacia Avenue, San Rafael, CA 94901; Kathleen Kosta, California Department of Food and Agriculture, 1220 N Street, Sacramento, CA 95814; Vernon Huffman, Supriya Sharma, and Karen Suslow, Department of Natural Sciences and Mathematics, Dominican University of California, 50 Acacia Avenue, San Rafael, CA 94901; and Sibdas Ghosh, Department of Natural Sciences and Mathematics, Dominican University of California, 50 Acacia Avenue, San Rafael, CA 94901 and School of Arts and Science, Iona College, 715 North Avenue, New Rochelle, NY 10801
\end{abstract}

Accepted for publication 21 January 2014. Published 13 March 2014.

\section{ABSTRACT}

Schweigkofler, W., Kosta, K., Huffman, V., Sharma, S., Suslow, K., and Ghosh, S. 2014. Steaming inactivates Phytophthora ramorum, causal agent of Sudden Oak Death and ramorum blight, from infested nursery soils in California. Plant Health Progress doi:10.1094/PHP-RS-13-0111.

Nursery trade plays a major role in the long-distance spread of Phytophthora ramorum, the causal agent of Sudden Oak Death (SOD) and ramorum blight of ornamental plants. Under federal regulations, nurseries found positive for P. ramorum must destroy infected plants and treat infested soils. The use of steam is an effective method to thermally inactivate $P$. ramorum from nursery soils as demonstrated at the
National Ornamental Research Site at Dominican University (NORSDUC) and one commercial nursery in the Central Valley of California. Heating up the top soil layer $(0-30 \mathrm{~cm})$ to $50^{\circ} \mathrm{C}$ for 120 minutes resulted in complete thermal inactivation of $P$. ramorum. Consequently, the commercial nursery was released from federal quarantine. Steaming can be a fast, reliable and sustainable option for treating nursery soils.

\section{INTRODUCTION}

Phytophthora ramorum Werres, De Cock \& Main in't Veld, is a new invasive plant pathogen that causes Sudden Oak Death (SOD), a devastating forest disease in California and Southwestern Oregon, characterized by extensive mortality of tanoak (Notholithocarpus densiflorus) and coast live oak (Quercus agrifolia) (11). Recently, a massive outbreak of disease in Japanese Larch (Larix kaempferi) plantations in the United Kingdom was associated with $P$. ramorum (15). In addition, $P$. ramorum causes ramorum blight on several economically important ornamental nursery plants, resulting in relatively minor leaf symptoms without killing the host. The nursery trade of symptomless but infected plant material plays an important role in the long-distance spread of the pathogen (6). In infested nurseries, $P$. ramorum can survive on plant debris, potting mix, soil in container fields, nursery equipment, and in water for extended periods of time. According to the federal quarantine program implemented by USDA APHIS (1), nursery soil which tests positive for $P$. ramorum has to be treated to eliminate the pathogen and minimize the risk for further dispersal.

The National Ornamental Research Site at Dominican University of California (NORS-DUC), is focused on the development and implementation of environmentally friendly solutions to stop the spread of pathogens of ornamental plants. The research site contains a mock nursery, which was developed

Corresponding author: Wolfgang Schweigkofler. Email: wolfgang.schweigkofler@dominican.edu

doi:10.1094/PHP-RS-13-0111 (C) 2014 The American Phytopathological Society to study quarantine pathogens under conditions similar to those typical of commercial nurseries (8).

Methods for eradication of pathogens include chemical, biological, and physical treatments. The aim of this study was to test (i) if steaming is a suitable method to inactivate $P$. ramorum from infested soils in a research nursery, (ii) the time frame and costs for a steaming event, and (iii) if steaming is an option for treating soil of a commercial nursery which is under federal quarantine.

\section{EFFECT OF WET HEATING AND DRY HEATING ON THE SURVIVAL OF P. RAMORUM}

Heat treatment is a well-established method to inactivate plant pathogens in nursery soils (2); however, because $P$. ramorum is a federally quarantined pest, soil disinfestation procedures must be planned and executed with the utmost caution as USDA has established a zero-tolerance management strategy. $P$. ramorum is a plant pathogen found in regions with temperate climate, and grows at temperatures between $2^{\circ} \mathrm{C}$ and $30^{\circ} \mathrm{C}$ with an optimum around $20^{\circ} \mathrm{C}(16)$. In order to simulate the effect of soil heating, we tested the impact of high temperatures on the growth of two $P$. ramorum isolates (Pr-1418886 and Pr-1418983-2) in the laboratory. Both strains originate from nurseries in Marin County, belong to clonal lineage NA1 and are of A2 mating type. Two heat sources were used: wet heating, which resembles the conditions in steamed soil; and dry heating. Leaves of Rhododendron catawbiense cv. English Roseum were inoculated with $P$. ramorum, incubated for three weeks at $20^{\circ} \mathrm{C}$, and leaf disks (diameter $5 \mathrm{~mm}$ ) overgrown with mycelium and chlamydospores were used for the thermal experiment. In order to test the effects of dry heating against wet heating, leaf disks were incubated at $30^{\circ} \mathrm{C}, 40^{\circ} \mathrm{C}, 50^{\circ} \mathrm{C}$, or $60^{\circ} \mathrm{C}$, respectively, for 30,60 , 
and 120 min in a dry incubator (Fisher Scientific, Hampton, NH; $\mathrm{RH}$ values varying from $31.3 \%$ at $30^{\circ} \mathrm{C}$ to $8.5 \%$ at $60^{\circ} \mathrm{C}$ ) or a water bath (Thermo Scientific, Waltham, MA). After treatment, leaf disks were plated on PARPH-V8 medium (5), incubated at $20^{\circ} \mathrm{C}$ for a week and the percentage of disks that yielded a colony of $P$. ramorum recorded. Experiments were done in triplicate; each replicate contained ten leaf disks. SPSS 12.0 (IBM Corp., Armonk, NY) for Windows was used for statistical analysis. The chi-square test was used to compare differences in survival rates between two isolates and wet vs. dry heating.

\section{SURVIVAL OF P. RAMORUM IN THE LABORATORY}

Effect of thermal treatment on the growth of $P$. ramorum is shown in Figure 1 (A, wet heating; B, dry heating). Incubation at $30^{\circ} \mathrm{C}$ for up to $120 \mathrm{~min}$ showed almost no effect on the survival rate. At $40^{\circ} \mathrm{C}$, growth rates were reduced in most cases except one isolate under wet heat. At $50^{\circ} \mathrm{C}$, wet heat treatment for $30 \mathrm{~min}$ inactivated $P$. ramorum completely (survival rate $=0 \%$ ). Dry heating at $50^{\circ} \mathrm{C}$ also lowered the growth rate, but was slightly less effective than wet heating (chi-square test, $P=0.00$ ). At $60^{\circ} \mathrm{C}$, $P$. ramorum was completely inactivated after $30 \mathrm{~min}$ of either wet or dry heat. Similar results have been reported for other plant pathogens (12). The two $P$. ramorum isolates differed in their reaction to heating, with Pr-1418886 showing slightly higher heat tolerance than Pr-1418983-2 (chi-square test; $P=0.06$ ). The morphological structures of Phytophthora spp. differ in their ability to resist adverse environmental conditions, with chlamydospores and oospores generally being more heat-stable than hyphae (14). Microscopic observations confirmed that our leaf disks contained both hyphae and chlamydospores. Oospore production of $P$. ramorum, which is a heterothallic species, has not been observed in the field (6). These results are in agreement with earlier reports by Linderman and Davis (9), who found that chlamydospores of $P$. ramorum mixed with plant potting medium were inactivated by aerated steam heat treatment of $50^{\circ} \mathrm{C}$ for 30 min; and Browning et al. (3), who reported that $P$. ramorum hyphae grown on V8 medium were inactivated after exposure to temperatures of 42.5 to $50^{\circ} \mathrm{C}$ at a thermal gradient plate for several minutes; whereas Harnik et al. (7) reported a $60 \%$ recovery rate of $P$. ramorum from infected California Bay Laurel (Umbellularia californica) leaves incubated at $55^{\circ} \mathrm{C}$ for one week.

\section{STEAMING AT A RESEARCH NURSERY AT NORS-DUC}

Dominican University of California is located in San Rafael, $\mathrm{CA}$, an area with a Mediterranean climate, with warm, dry summers (average highs $27^{\circ} \mathrm{C}$ in August) and mild, rainy winters (average lows around $6^{\circ} \mathrm{C}$ in December) and total annual precipitation averages $817 \mathrm{~mm}$. The steaming experiments were carried out in research beds with a surface area of $3.7 \mathrm{~m} \times 4.6 \mathrm{~m}$ $\left(17 \mathrm{~m}^{2}\right)$ which were lined with water-proof liners. The beds were filled with a $30-\mathrm{cm}$-deep layer of gravelly loam soil with a $\mathrm{pH}$ of 5.8 and $5.9 \%$ organic matter; which was originally excavated
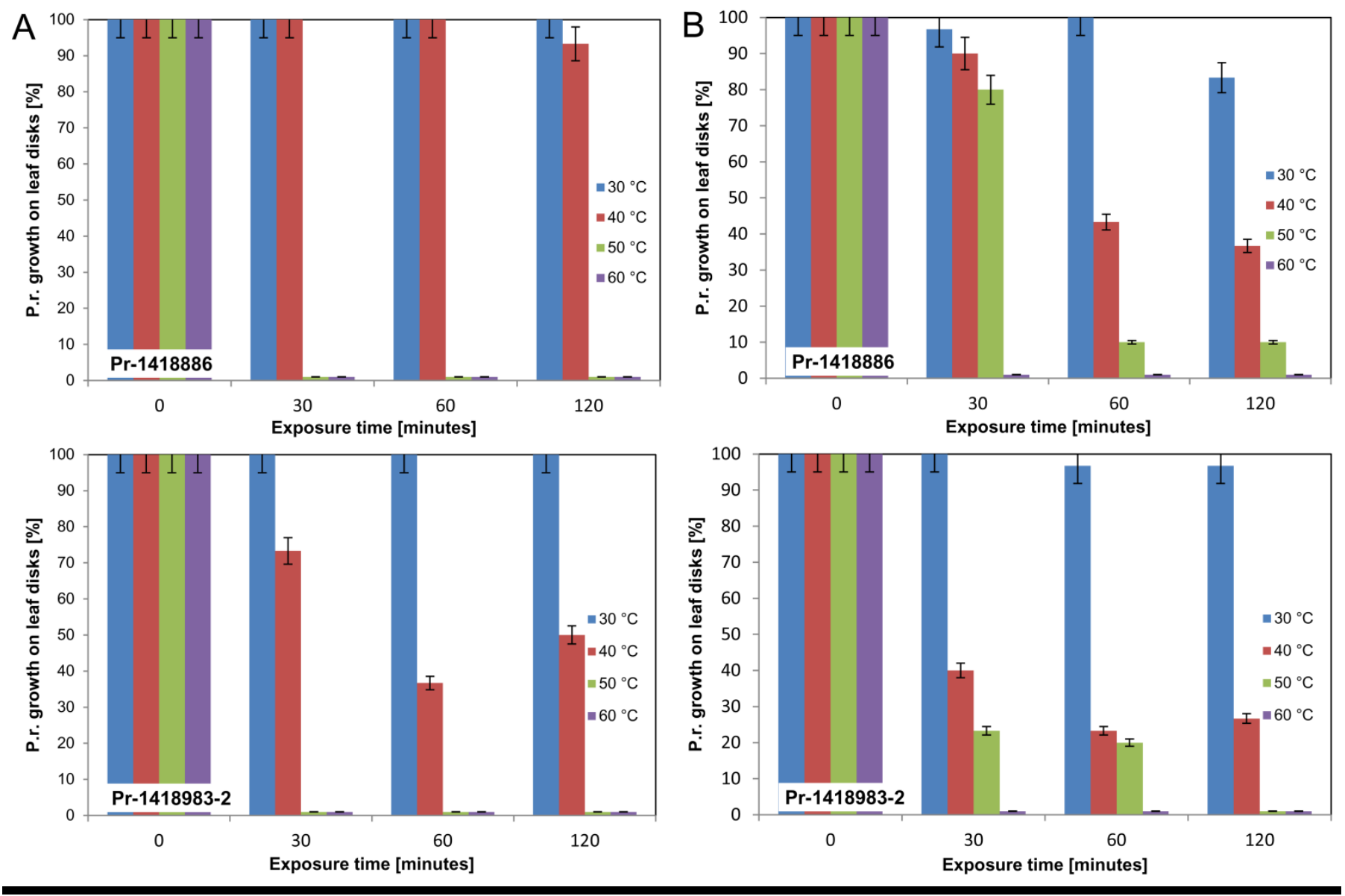

FIGURE 1

Effect of thermal treatment on the growth of $P$. ramorum isolates Pr-1418886 and Pr-1418983-2. Infected Rhododendron leaf disks were incubated at $30,40,50$, and $60^{\circ} \mathrm{C}$ for 30,60 , and $120 \mathrm{~min}$, respectively, in (A) a water bath (wet heat) or (B) an incubator (dry heat). Error bars indicate $95 \%$ confidence intervals. 
from the Dominican campus. A steamer unit SIOUX Steam-Flo SF-11 (Sioux Corp., Beresford, SD, USA) with a boiler horsepower of 10.67 and a steaming output of 168 liters/h was used with an attached soaker hose (length $31 \mathrm{~m}$ ) laid out on the soil surface, which then was covered with a waterproof, pond liner-type tarp. A total of five soil steaming events were carried out at NORS-DUC between July 2012 and February 2013. In addition, nine steaming events were carried out on research beds filled with potted plants (Rhododendron sp. and Viburnum sp.), which were used previously for $P$. ramorum infection studies. For all steaming experiments, the minimum soil temperature of $50^{\circ} \mathrm{C}$ was kept for 120 min ('inactivation period') before turning off the steamer.

\section{STEAMING AT A COMMERCIAL NURSERY IN THE CENTRAL VALLEY, CA}

Preliminary work at a commercial nursery in Stanislaus County, CA, which had been found to have $P$. ramorum infested soil in the container field, indicated that steam could inactivate the pathogen from nursery soil (unpublished data, S. JohnsonBrousseau). Another nursery, also found with $P$. ramorum infested soil, was selected for further steam treatment studies. The commercial retail nursery was located in Sacramento, CA, an area with Mediterranean climate, with hot, dry summers (average highs $33^{\circ} \mathrm{C}$ in August) and mild, rainy winters (average lows around $3^{\circ} \mathrm{C}$ in December); total annual precipitation averages $470 \mathrm{~mm}$. Loropetalum sp. plants infected with $P$. ramorum were detected during an annual nursery inspection in the spring of 2012. Baiting of the soil on which the potted plants were kept, conducted by the California Department of Food and Agriculture (CDFA) found the soil to be infested with P. ramorum. The area

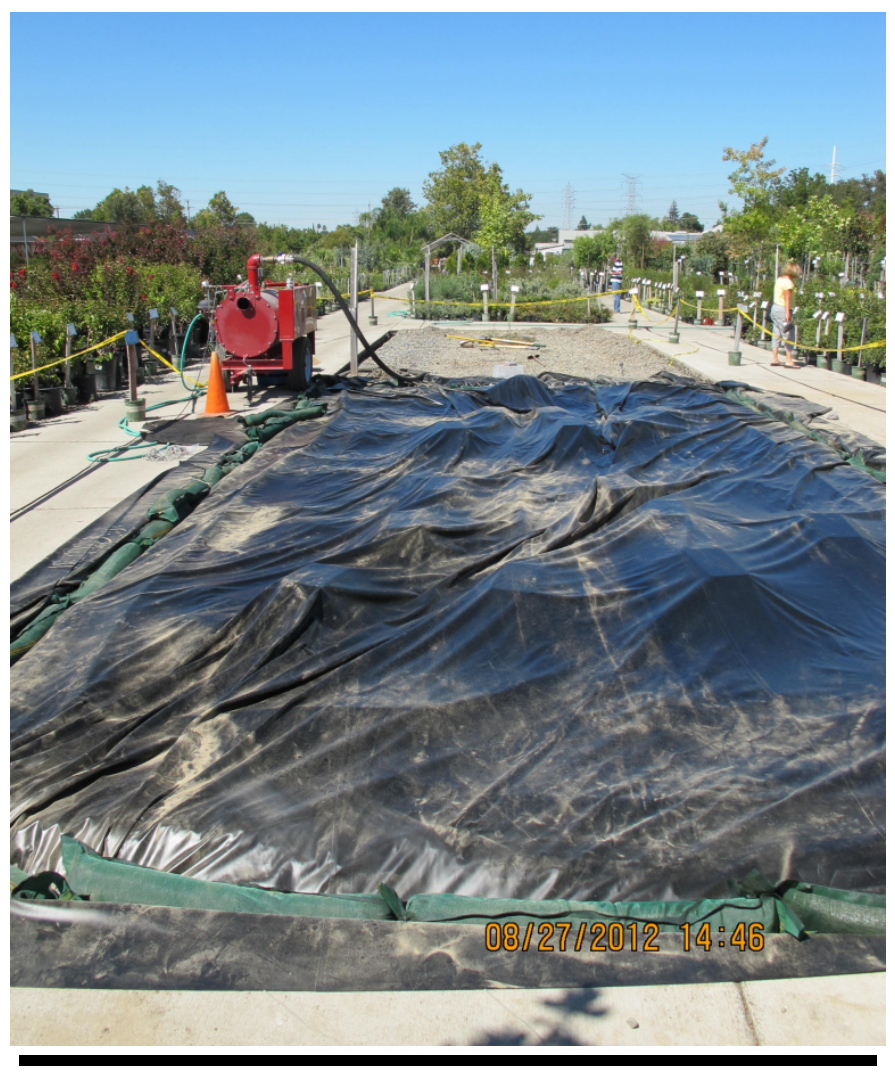

FIGURE 2

Thermal treatment of nursery soil in the Central Valley, California, using a steaming unit SIOUX Steam-Flo SF-11 (Sioux Corp., Beresford, SD). put under quarantine was $20.5 \mathrm{~m} \times 5.3 \mathrm{~m}\left(108.7 \mathrm{~m}^{2}\right)$, composed of a layer of coarse gravel (approximately $30 \mathrm{~cm}$ deep, consisting of approximately $3 / 4$-inch rocks) over sandy loam. The area to be steam treated was completely saturated with water from previous irrigations. The nursery bed was divided into two areas of $54.3 \mathrm{~m}^{2}$ each, and treated on two subsequent days in August 2012.

\section{MEASUREMENT OF TEMPERATURE AND SURVIVAL RATES}

Soil temperatures were measured using HOBO-data loggers

U12 (Onset Corp., Cape Cod, MA, USA) with sensors positioned at 5,15 , and $30 \mathrm{~cm}$, respectively, below surface. Temperature data were collected at a 15-min interval. To serve as the positive control at the contained research site, 20 Rhododendron leaf disks overgrown with mycelium and chlamydospores of $P$. ramorum isolate Pr-1418886 were placed in sachets and buried at the deepest soil layer prior to steaming. After steaming, the leaf disks were plated on PARPH-V8 plates, incubated in the dark at $20^{\circ} \mathrm{C}$ for two weeks and then checked for growth. As a control, leaf disks infected with $P$. ramorum, but not-heat treated, were plated onto PARPH-V8. Phytophthora ramorum infested leaf disks could not be used at the commercial nursery due to regulations. Soil samples from the commercial nursery were tested for $P$. ramorum before and after treatment by a soil-baiting technique using Rhododendron leaves at both the NORS-DUC and the CDFA labs.

\section{THERMAL INACTIVATION OF SOIL BORNE P. RAMORUM}

Soil contained in a research bed used for studies on $P$. ramorum in a mock nursery was treated with aerated steam using a commercial steaming unit (Fig. 2). The soil temperature was measured from sensors strategically positioned at different areas within the research beds as well as at different soil depths. Three representative steaming experiments are described in more detail: the experiments 1 and 2 were carried out at NORS-DUC in different seasons (1 in July 2012, 2 in February 2013), and experiment 3 was carried out at a retail nursery in Sacramento in August 2012. Temperature profiles show different dynamics depending on soil depths. Experiment 1 (Fig. 3A) started from an ambient air temperature of $18^{\circ} \mathrm{C}$; the target temperature of $50^{\circ} \mathrm{C}$ at 5 -cm soil depth was reached after approximately $1 \mathrm{~h}$, at $15 \mathrm{~cm}$ after $2 \mathrm{~h}$, and at $30 \mathrm{~cm}$ after $6 \mathrm{~h}$. The heat source was turned off $2 \mathrm{~h}$ after reaching the target temperature, after which temperatures close to the surface dropped quickly, whereas those at $30 \mathrm{~cm}$ rose for several degrees due to continued heat transfer from the upper layers, before declining steadily. Maximum temperatures are difficult to control with this approach; close to the soil surface temperatures above $90^{\circ} \mathrm{C}$ can be achieved. Soil temperatures remain well above ambient temperatures for up to three days poststeaming (data not shown).

Experiment 2 (Fig. 3B) started from an ambient air temperature of approximately $10^{\circ} \mathrm{C}$; the target temperature of $50^{\circ} \mathrm{C}$ at $5-\mathrm{cm}$ soil depth was reached after approximately $4 \mathrm{~h}$, at $15 \mathrm{~cm}$ after $9 \mathrm{~h}$ and at $30 \mathrm{~cm}$ after $12 \mathrm{~h}$. Experiment 3 (Fig. 3C) started from an ambient air temperature of approximately $20^{\circ} \mathrm{C}$; the target temperature of $50^{\circ} \mathrm{C}$ at $5-\mathrm{cm}$ soil depth was reached after approximately $2 \mathrm{~h}$, at $15 \mathrm{~cm}$ after $5 \mathrm{~h}$, and at $30 \mathrm{~cm}$ after $9.5 \mathrm{~h}$.

The dynamics of the temperature increase in different soil depths and the time needed to reach the target temperature of 50 are influenced by several parameters, among them ambient temperature and soil water content. Experiment 1, conducted on 10 July 2012 in San Rafael, CA, with an average air temperature of $18^{\circ} \mathrm{C}$ (maximum $25.5^{\circ} \mathrm{C}$ ) and dry soil conditions resulted in a steep increase of the soil temperatures. Experiment 2, conducted on 6 February 2013 using the same soil but at lower ambient air temperatures (average $9.7^{\circ} \mathrm{C}$, maximum $12.8^{\circ} \mathrm{C}$ ), showed a much 
slower temperature increase. Soils at the commercial nursery (experiment 3), which were treated at on 28 August 2012 with a average air temperature of $23.6^{\circ} \mathrm{C}$ (maximum $34^{\circ} \mathrm{C}$ ), heated up slowly because of high water content.

Steaming of research beds filled with remains of infection studies on potted plants, including pots, root balls, etc., was characterized by very fast temperature increase. Temperatures reached the target temperature of $50^{\circ} \mathrm{C}$ at the center of a root ball in a one-gallon pot after one hour and rose to $>80^{\circ} \mathrm{C}$ (data not shown).
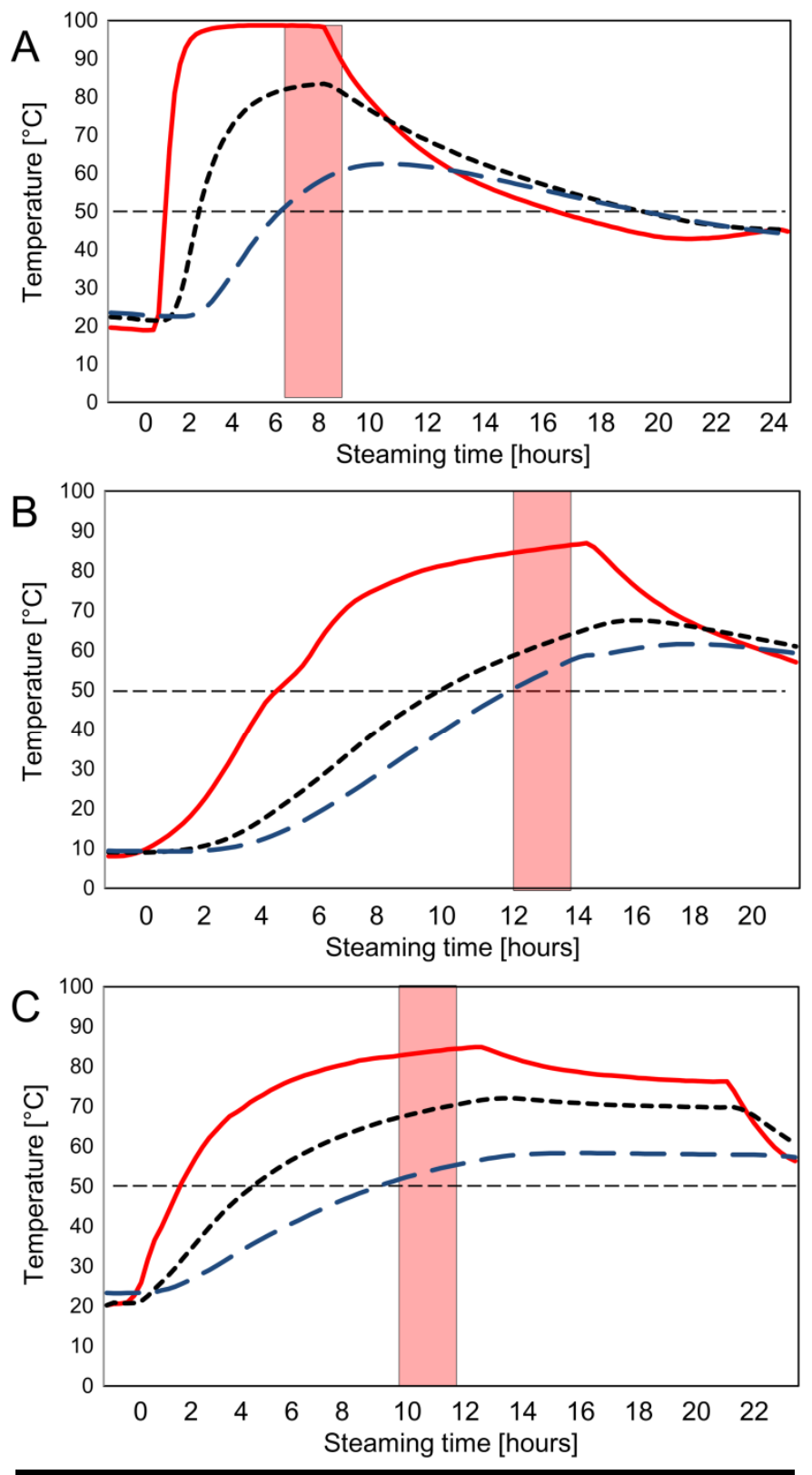

\section{FIGURE 3}

Temperature profiles of three steaming events: $(\mathbf{A})$ research nursery at NORS-DUC, July 2012; (B) research nursery at NORS-DUC, February 2013; (C) commercial nursery in the Central Valley, California, August 2012. Temperatures were measured at depths of $5 \mathrm{~cm}$ (red line), 15 $\mathrm{cm}$ (black line), and $30 \mathrm{~cm}$ (blue line). The horizontal line shows the target temperature of $50^{\circ} \mathrm{C}$. The "inactivation period" (defined as the time between reaching the target temperature and turning off the steamer) is shown in red.
The heat treatment successfully inactivated $P$. ramorum in the soil and on potted plants (Table 1); no growth was detected after incubation of the leaf disks which were steamed at NORS-DUC (survival rate $=0 \%$ ), whereas $P$. ramorum cultures developed from each control leaf disk (survival rate $=100 \%$ ). Soil samples from the commercial nursery post-treatment were tested negative using a soil-baiting method; Rhododendron leaves were incubated with a soil-water mix at $20^{\circ} \mathrm{C}$ for two days and subsequently leaf disks plated on PARPH-V8 plates. The nursery was consequently released from quarantine.

The maximum soil depth in our experiments $(30 \mathrm{~cm})$ was limited by the dimensions of the lined research beds at NORSDUC. However, the presence of $P$. ramorum in infected nursery soil is largely limited to the top soil layer. In a study on $P$. ramorum in nursery soils in Washington State, Dart et al. (4) discovered $86 \%$ of soil inoculum in the organic layer or the top 0$5 \mathrm{~cm}$ of soil, with no detection occurring below $10 \mathrm{~cm}$. In our experiments, temperatures at the $5-\mathrm{cm}$ soil layer reached between $84.7^{\circ} \mathrm{C}$ and $98.7^{\circ} \mathrm{C}$, and at the $15-\mathrm{cm}$ soil between $67.5^{\circ} \mathrm{C}$ and $83.4^{\circ} \mathrm{C}$ (Fig. 3). Provided that distribution of P. ramorum is similar in nursery soils in different geographic locations, heat treatment of the top $30 \mathrm{~cm}$ soil layer should result in complete deactivation of $P$. ramorum. Further support for the usefulness of thermal inactivation of $P$. ramorum comes from a recent study by Parke and Funahashi (10) at NORS-DUC, who used solarization to heat up soil to a maximum temperature of approximately $50^{\circ} \mathrm{C}$ to inactivate inoculum grown on leaf disks.

Compared to other treatment options for nursery soils and plants infested with $P$. ramorum, steaming is considerably faster than solarization or biological control and more sustainable than using concrete or fumigation. Composting is an effective way to inactivate $P$. ramorum in infected plant debris (13), but also slower and not suitable for soil. Steaming can also be used to disinfect nursery equipment, such as used pots, to reduce possible spread of $P$. ramorum within the nursery. Apart from the cost of the equipment, steaming is also relatively cheap: consumables for running the steamer are fuel (diesel), which in our experiments averaged 11.5 liters/h resulting in a total of 92 liters (experiment 1) to 161 liters (experiment 2), as well as water and electricity.

Additional studies to inactivate $P$. ramorum from infested soils are under way at NORS-DUC using a newly developed formulation of the biocontrol agent Trichoderma asperellum and solarization. Steaming will be further tested at several commercial nurseries in three western U.S. states to compare the effects of different climate and soil on steaming success. The final goal of these studies is to develop guidelines for the nursery industry offering several sanitization options optimized for different situations and needs.

\section{ACKNOWLEDGMENTS}

We thank S. Johnson-Brousseau, G. Copeland, and M. Henkes for their efforts to develop and initiate the early work at NORSDUC. We especially would like to thank the owners and managers of the nurseries who agreed to participate in the study. Our thanks to Drs. Suzanne Rooney Latham and Cheryl Blomquist from the CDFA Plant Pest Diagnostic Laboratory for their continued support and collaboration. CDFA completed the mandatory soil testing required at the commercial nurseries, as per the federal regulations. NORS-DUC is funded by a grant from the 2008 Farm Bill, Section 10201, and administrated through the United States Department of Agriculture (USDA) Animal and plant Health Inspection Service (APHIS) Plant Protection and Quarantine (PPQ) Centre for Plant Health Science and Technology (CPHST). 


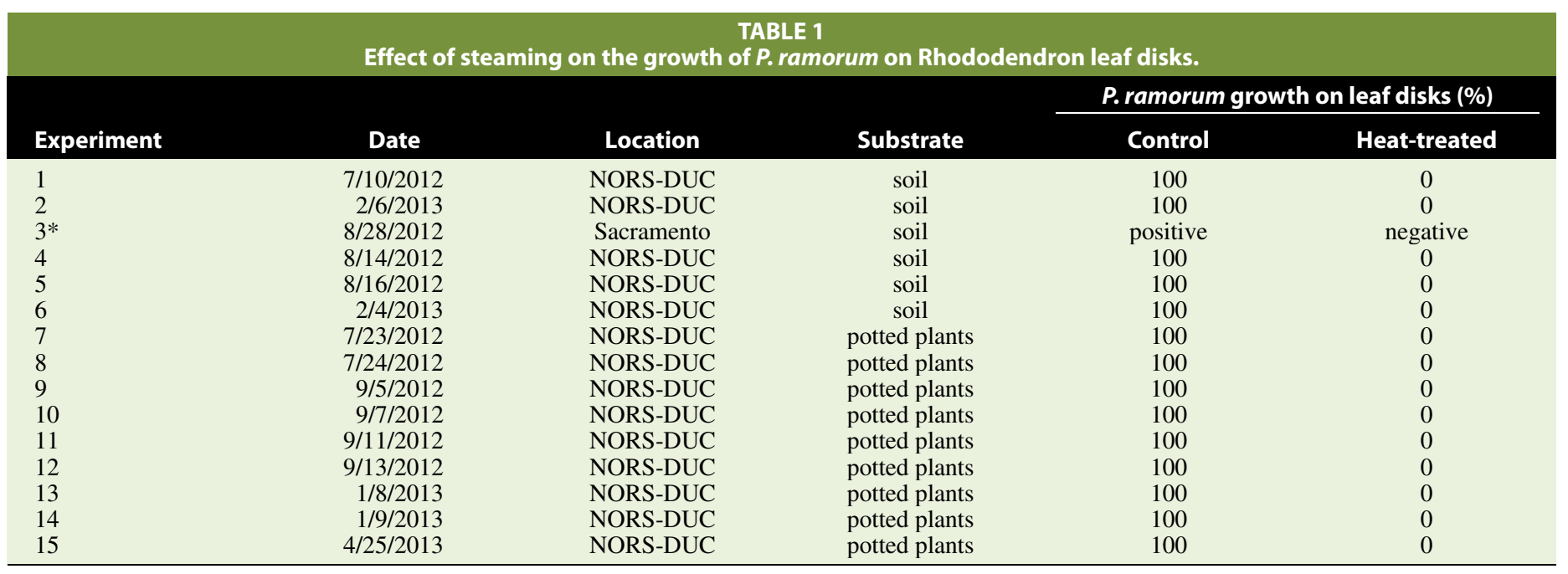

* Soil at the commercial nursery (experiment 3 ) was tested using a non-quantitative soil-baiting technique.

\section{LITERATURE CITED}

1. APHIS, USDA. 2007. Rules and regulations: Phytophthora ramorum; quarantine and regulations. 7 CFR Part 301. Federal Register 72(38):8585-8604.

http://www.aphis.usda.gov/plant_health/plant_pest_info/pram/downloads/ pdf files/01-064-3.pdf

2. Baker, K. F., and Roistacher, C. N. 1957. Heat treatment of soil. Pages 123-137 in: The U.C. System for Producing Healthy Container-grown Plants. K. F. Baker, ed. Ext. Serv. Manual 23, California Agricultural Experimental Station.

3. Browning, M., Englander, L., Tooley, P. W., and Berner, D. 2008. Survival of Phytophthora ramorum hyphae after exposure to temperature extremes and various humidities. Mycologia 100:236-245.

4. Dart, N. L., Chastagner, G. A., Rugarber, E. F., and Riley, K. L. 2007. Recovery frequency of Phytophthora ramorum and other Phytophthora spp. in the soil profile of ornamental retail nurseries. Plant Dis. 91:14191422.

5. Ferguson, A. J., and Jeffers, S. N. 1999. Detecting multiple species of Phytophthora in container mixes from ornamental crop nurseries. Plant Dis. 83:1129-1136.

6. Grünwald, N. J., Garbelotto, M., Goss, E. M., Heungens, K., and Prospero, S. 2012. Emergence of the sudden oak death pathogen Phytophthora ramorum. Trends Microbiol. 20:131-138.

7. Harnik, T. Y., Mejia-Chang, M., Lewis, J., and Garbelotto, M. 2004. Efficacy of heat-based treatments in eliminating the recovery of the Sudden Oak Death pathogen (Phytophthora ramorum) from infected California Bay laurel leaves. HortScience 39:1677-1680.

8. Johnson-Brousseau, S., Henkes, M., Kosta, K., Suslow, K., Posadas, A., and Ghosh, S. 2011. Phytophthora ramorum research at the National
Ornamental Research site at the Dominican University of California. N. Z. J. For. Sci. 41S:101-113.

9. Linderman, R. G., and Davis, E. A. 2008. Eradication of Phytophthora ramorum and other pathogens from potting medium or soil by treatment with aerated steam or fumigation with metam sodium. HortTechnology 18:106-110.

10. Parke, J., and Funahashi, F. 2013. Putting the sun to work. Solarization can be an effective way to kill pests, pathogens and weeds. Oregon State Univ., Digger, June 2013, pages 33-36.

11. Rizzo, D. M., Garbelotto, M., Davidson J. M., Slaughter, G. W., and Koike S. T. 2002. Phytophthora ramorum as the cause of extensive mortality of Quercus spp. and Lithocarpus densiflorus in California. Plant Dis. $86: 205-214$

12. Shlevin, E., Saguy, I. S., Mahrer, Y., and Katan, J. 2003. Modeling the survival of two soilborne pathogens under dry structural solarization. Phytopathology 93:1247-1257.

13. Swain, S. Harnik, T., Mejia-Chang, M., Hayden, K., Creque, J., and Garbelotto, M. 2006. Composting is an effective treatment option for sanitization of Phytophthora ramorum-infected plant material. J. Appl. Microbiol. 101:815-827.

14. Tooley, P. W., Browning, M., and Berner, D. 2008. Recovery of Phytophthora ramorum following exposure to temperature extremes. Plant Dis. 92:431-437.

15. Webber, J. F., Mullet, M., and Brasier, C. M. 2010. Dieback and mortality of plantation Japanese larch (Larix kaempferi) associated with infection by Phytophthora ramorum. New Dis. Rep. 22:19. doi:10.5197/j.20440588.2010.022.019.

16. Werres, S., Marwitz, R., Man in't Veld, W. A., De Cock, A. W. A. M., Bonants, P. J. M., De Weerdt, M., Themann, K., Ilieva, E., and Baayen, R. 2001. Phytophthora ramorum sp. nov., a new pathogen on Rhododendron and Viburnum. Mycol. Res. 105:1155-1165. 